\title{
Insulin-like growth factor-I promotes migration in human androgen-independent prostate cancer cells via the avB3 integrin and PI3-K/Akt signaling
}

\author{
MARINA MONTAGNANI MARELLI ${ }^{1}$, ROBERTA M. MORETTI ${ }^{1}$, PATRIZIA PROCACCI ${ }^{2}$, \\ MARCELLA MOTTA $^{1}$ and PATRIZIA LIMONTA ${ }^{1}$ \\ ${ }^{1}$ Center for Endocrinological Oncology, Institute of Endocrinology, ${ }^{2}$ Institute of Histology, \\ Embryology and Neurocytology, University of Milano, Milano, Italy
}

Received September 8, 2005; Accepted October 31, 2005

\begin{abstract}
In its phase of androgen-independence, prostate carcinoma is characterized by a high proliferation rate and by a strong ability to give rise to metastases. IGF-I has been shown to exert a potent mitogenic action on prostate cancer. We investigated whether IGF-I might also affect the motility of prostate cancer cells and defined the mechanism of action. We found that IGF-I promotes the migratory capacity of androgen-independent prostate cancer cells through the activation of its specific receptor, IGF-IR. This effect was accompanied by a change in cell morphology (as revealed by scanning electron microscopy), and by a rearrangement of the actin cytoskeleton. The treatment of cells with the PI3-K inhibitor, LY294002, counteracted the pro-migratory activity of IGF-I. Experiments were then performed to clarify whether the integrin, $\alpha v ß 3$, could be involved in the action of IGF-I. We demonstrated that: a) the IGF-I-induced migration of cells is completely antagonized by an antibody specifically blocking the function of $\alpha v \beta 3$; b) IGF-I increases $\alpha v \beta 3$ immunofluorescence at the level of cell membranes, and this effect is counteracted by LY294002; and c) IGF-I increases $\alpha \mathrm{V} ß 3$ protein levels. Our results demonstrate that IGF-I promotes the motility of androgen-independent prostate cancer cells by modulating $\alpha \mathrm{v} ß 3$ integrin activation/expression; these effects are mediated by the PI3-K/Akt signaling pathway. This study: a) supports a crucial role for IGF-I in the progression of the pathology towards the highly metastatic phase; and b) provides an additional rationale basis for the development of therapeutic strategies directed at the IGF-I/IGF-IR system in the treatment of androgen-independent prostate cancer.
\end{abstract}

Correspondence to: Dr Patrizia Limonta, Center for Endocrinological Oncology, Institute of Endocrinology, University of Milano, Via Balzaretti 9, I-20133 Milano, Italy

E-mail: patrizia.limonta@unimi.it

Key words: IGF-I, prostate cancer, cell motility, integrins, PI3-K/Akt

\section{Introduction}

Despite the intensive research aimed at identifying new and more successful therapeutical approaches, prostate cancer still remains the second cause of cancer deaths in males in Western countries (1). In its initial stages, prostate carcinoma is usually androgen-dependent, and the majority of patients positively respond to a therapy based on androgen ablation or blockade of androgen action (2). However, after a period of remission, almost invariably, the pathology progresses to a condition of androgen-independence (3) characterized by a high proliferation rate and by a strong ability to give rise to metastases $(4,5)$. The therapeutical options for hormoneresistant prostate cancer are still very limited $(6,7)$.

The insulin-like growth factor-I (IGF-I) system has been implicated in the control of growth of several common neoplasias (8). In particular, there is now strong evidence, both from experimental and from epidemiological studies, that a close association exists between IGF-I and IGF-I receptors (IGF-IR) and prostate cancer growth (9). Prostate cancer cells produce IGF-I, express IGF-IR and exhibit a significant responsiveness to the mitogenic activity of IGF-I in vitro (10-13), while IGF-IR inhibition by means of antisense RNA reduces prostate cancer cell proliferation (14). The androgendependent prostate cancer LNCaP cell line expresses the IGF-I system and responds to IGF-I with increased proliferation; when these cells are induced to progress to an androgenindependent condition, they exhibit increased expression and signaling of IGF-IR (15). In in vivo studies (performed in SCID mice), the progression of androgen-dependent prostate cancer xenografts (derived from the LAPC-9 and LNCaP cell lines) towards a phase of androgen-independence is associated with increased levels of both IGF-I and IGF-IR (16); similarly, prostate-specific IGF-I mRNA expression was found to increase during prostate cancer progression in TRAMP mice and to be elevated in the accompanying metastases (17). Finally, elevated serum levels of IGF-I have been reported to be associated with an increased risk of prostate cancer in men $(18,19)$, and the level of expression of IGF-IR, which is up-regulated in primary prostate cancer, seems to persist in metastatic disease (20).

Taken together, these observations point to IGF-I as a crucial mitogenic factor involved in prostate cancer develop- 
ment and progression. However, although the proliferative and antiapoptotic effects of IGF-I in prostate cancer are now well established, the data on a possible direct effect of this growth factor on the metastatic behavior of prostate cancer cells are still scanty.

Metastasis is a complex process in which cancer cells detach from the primary tissue and acquire the ability to migrate towards target tissues where they give rise to colonies. Integrins, the heterodimeric proteins that mediate cell adhesion to the extracellular matrix, are known to be deeply involved in the processes of cell migration and invasion (21). In prostate cancer, the integrin dimer, $\alpha \mathrm{v} ß 3$, seems to be particularly involved in the progression of the pathology, being highly expressed in metastatic androgen-independent (PC3) but absent in less aggressive hormone-dependent ( $\mathrm{LNCaP}$ ) prostate cancer cells (22).

In the present study, we investigated the effects of IGF-I on the migratory behavior of androgen-independent prostate cancer cells; the involvement of the $\alpha v ß 3$ integrin as well as the intracellular signaling pathway mediating the action of IGF-I have also been defined.

\section{Materials and methods}

Materials. Human recombinant IGF-I was purchased from Peprotech EC, Ltd. (London, UK) and neutralizing antiIGF-IR mAb $\alpha$ IR3 was obtained from Oncogene Research Products (San Diego, CA). Mouse anti- $\alpha$ VB3 antibody was from Chemicon (Temecula, CA). The phosphatidylinositol3kinase (PI3-K) inhibitor, LY294002; the MAP kinase inhibitor, UO126; rabbit anti-mouse antibody and vitronectin were from Sigma Chemical Co. (St. Louis, MO). Fibronectin was from Seromed Biochrom (Berlin, Germany).

Cell cultures. Human androgen-independent DU 145 and PC3 prostate cancer cell lines were obtained from American Type Culture Collection (Rockville, MD). Cells were routinely grown in RPMI medium (Seromed Biochrom) supplemented with fetal bovine serum (FBS; Gibco, Paisley, Scotland, UK) (5\% for DU 145 and 10\% for PC3 cells), glutamine (1 mM) and antibiotics (100 U/ml penicillin $\mathrm{G}$ sodium, $100 \mu \mathrm{g} / \mathrm{ml}$ streptomycin sulphate) in a humidified atmosphere of $5 \% \mathrm{CO}_{2} / 95 \%$ air.

Chemomigration assay. Cell migration was analyzed by means of chemomigration assays, using a 48-well Boyden's chamber ( $8-\mu \mathrm{m}$ pore size) and according to the manufacturer's instructions (Neuroprobe, Cabin John, MD), as previously described (23). After the specific treatments (see below), subconfluent DU 145 cells were harvested and cell suspensions $\left(1.5 \times 10^{5}\right.$ cells $\left./ 50 \mu \mathrm{l}\right)$ were placed in the open bottom wells of the upper compartment of the chamber. The chemoattractant (20\% FBS) was placed in the lower compartment of the chamber. The chamber was then kept for $4 \mathrm{~h}$ in the cell culture incubator. After that, the cells that had migrated through the pores and had adhered to the underside of the membrane were fixed, stained (Diff-Quick kit; DADE, Dudingen, $\mathrm{CH}$ ) and mounted onto glass slides. For quantitative analysis, six random objective fields of stained cells were counted for each well ( 8 wells/experimental group) and the mean number of migrated cells $/ \mathrm{mm}^{2}$ was calculated.
Experiment 1: To evaluate the role of the IGF-IR in the control of prostate cancer cell migration, DU 145 cells, in complete medium (FBS supplemented), were treated with the IGF-IR $\alpha$ IR 3 monoclonal antibody $(1 \mu \mathrm{g} / \mathrm{ml})$ for $1 \mathrm{~h}$, before being harvested and seeded in the wells for the migration assay.

Experiment 2: To confirm the effect of IGF-I on cell motility, DU 145 cells, in serum-free medium, were treated with IGF-I (10 nM) for $24 \mathrm{~h}$. During the last hour of treatment, the IGF-IR antibody $(1 \mu \mathrm{g} / \mathrm{ml})$ was added to the incubation medium. Cells were then harvested and seeded in the wells for the assay.

The specific pro-migratory effect of IGF-I on DU 145 prostate cancer cells was further investigated in another androgen-independent prostate cancer cell line (PC3). These experiments were performed as described above for DU 145 cells (same dose of IGF-I or IGF-IR antibody, same length of treatment, etc.).

Experiment 3: To investigate the possible intracellular pathways involved in the activity of IGF-I, DU 145 cells, in serum-free medium, were incubated for $45 \mathrm{~min}$ with the PI3-K inhibitor, LY294002 $(20 \mu \mathrm{M})$, before treatment with IGF-I $(10 \mathrm{nM})$ for $30 \mathrm{~min}$. Cells were then harvested and seeded in the wells for the assay. A similar experiment was performed using the MAP kinase inhibitor, UO126 $(10 \mu \mathrm{g} / \mathrm{ml})$.

In each of these assays, triplicate wells were performed, and the assay was repeated three times. The data were analyzed according to Bonferroni's test after one-way ANOVA.

Scanning electron microscopy. For scanning electron microscopy, fibronectin-coated coverslips were incubated in serum-free medium with or without IGF-I (10 nM) for $30 \mathrm{~min}$. The cells were washed in PBS for 10 min, fixed in $2 \%$ glutaraldehyde in $0.1 \mathrm{M}$ cacodylate buffer and then washed in the same buffer. Coverslips were post-fixed in aqueous $4 \% \mathrm{OsO}_{4}$ for $20 \mathrm{~min}$, washed in distilled water for $10 \mathrm{~min}$, immersed in aqueous $1 \%$ tannic acid for $20 \mathrm{~min}$ and washed in distilled water for $10 \mathrm{~min}$. This procedure was repeated 3 times at room temperature. Cells were dehydrated in alcohol, immersed in isoamylacetate and dried using the critical-point method. Coverslips were sputter-coated with gold/palladium and observed under a scanning electron microscope (Autoscan Siemens). This experiment was repeated two times for two different preparations.

Haptotactic assay. Haptotactic assays were performed in a Boyden's chamber, in which the lower surface of the membrane had been precoated with fibronectin $(12 \mu \mathrm{g} / \mathrm{ml})$ [one of the proteins of the extracellular matrix to which avß3 integrin binds (21)]. The assay was then performed as described above.

Experiment 1: To clarify the role of the $\alpha \mathrm{v} ß 3$ integrin in the migration of prostate cancer cells towards fibronectin, DU 145 cells were plated at a density of $5 \times 10^{5}$ cells/plate and cultured, in complete medium, either in the absence or in the presence of the function blocking avß3 antibody $(1 \mu \mathrm{g} / \mathrm{ml})$ for $1 \mathrm{~h}$. Cells were then harvested and seeded in the wells of the Boyden's chamber.

Experiment 2: To verify whether the $\alpha \mathrm{v} ß 3$ integrin mediates the activity of IGF-I on prostate cancer cell motility towards fibronectin, DU 145 cells, in serum-free media, were 
A

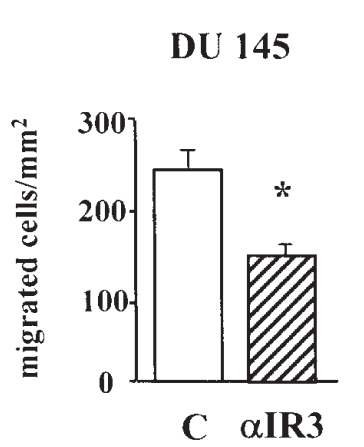

B

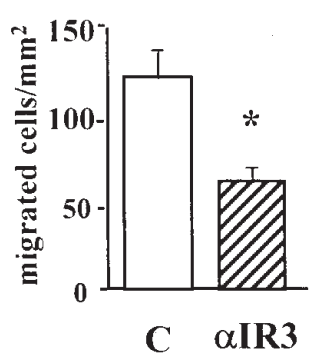

Figure 1. Effect of the neutralizing antibody, anti-IGF-IR $\alpha$ IR3, on the motility of androgen-independent prostate cancer cells. DU 145 and PC3 cells, cultured in complete medium (i.e. supplemented with 5 and $10 \%$ FBS, respectively), were treated with $\alpha \mathrm{IR} 3(1 \mu \mathrm{g} / \mathrm{ml})$ for $1 \mathrm{~h}$ before beeing seeded in the wells of a Boyden's chamber. The chemomigration assay was then performed as outlined in Materials and methods. C, controls. Results are expressed as the mean number of migrated cells $/ \mathrm{mm}^{2} \pm \mathrm{SE} .{ }^{*} \mathrm{P}<0.05 \mathrm{vs}$. C.

stimulated with IGF-I $(10 \mathrm{nM})$ for $24 \mathrm{~h}$. The function blocking antibody against $\alpha v B 3(1 \mu \mathrm{g} / \mathrm{ml})$ was added to the culture medium during the last hour before the haptotactic assay.

In each of these assays, triplicate wells were performed, and the assay was repeated three times. The data were analyzed according to Bonferroni's test after one-way ANOVA.

Immunofluorescence analysis. The effects of IGF-I on actin and avß3 integrin immunolocalization were evaluated by immunofluorescence using standard techniques. DU 145 cells were grown on 22-mm glass coverslips and treated, in serumfree conditions, with IGF-I ( $10 \mathrm{nM})$ for $30 \mathrm{~min}$. To visualize filamentuous actin (F-actin), cells were fixed with 3.7\% paraformaldehyde in PBS for 15 min, permeabilized with $0.2 \%$ Triton X-100 in PBS for $1 \mathrm{~min}$ and stained with fluorescein isothiocyanate (FITC)-phalloidin $(0.4 \mu \mathrm{g} / \mathrm{ml})$ (Sigma Chemical Co.).

For visualization of the effects of IGF-I on $\alpha \mathrm{v} ß 3$ integrin expression, cells were incubated with LY294002 $(20 \mu \mathrm{M}$, $45 \mathrm{~min}$ ) before treatment with IGF-I (10 nM, $30 \mathrm{~min})$. Paraformaldehyde-fixed cells were incubated with an unlabeled anti- $\alpha$ vB3 primary antibody, followed by fluorescein isothiocyanate (FITC)-conjugated goat anti-mouse secondary antibody. Labeled cells were examined under a Zeiss Axiovert 200 microscope with a $63 x / 1.4$ objective lens. Images were acquired using the Metavue program and analyzed using Adobe Photoshop 6.0. Each staining was repeated three times for three different preparations for each group.

Biothynilation and immunoprecipitation of the $\alpha v \beta 3$ integrin. Experiments were performed as previously described (23). To clarify whether IGF-I could affect the levels of avß3 protein, DU 145 cells, grown in serum-free medium, were treated with IGF-I $(10 \mathrm{nM})$, for $24 \mathrm{~h}$. The cells were then washed five times with Hank's buffer and incubated with $2 \mathrm{ml}$ of Hank's buffer supplemented with $500 \mu \mathrm{g} / \mathrm{ml}$ sulfoccinimidyl hexanoate-conjugated biotin (NHS-LC-Biotin; Pierce Biotechnology Inc., Rockford, IL) to label cell surface proteins for $30 \mathrm{~min}$ at $4^{\circ} \mathrm{C}$. Cells were washed three times and lysed in $0.5 \mathrm{ml}$ RIPA buffer (0.05 M Tris. $\mathrm{HCl} \mathrm{pH} 7.7,0.15 \mathrm{NaCl}$,
$0.8 \%$ SDS, $10 \mathrm{mM}$ EDTA, $100 \mu \mathrm{M} \mathrm{NaVO}_{4}, 50 \mathrm{mM} \mathrm{NaF}$, $0.3 \mathrm{mM}$ PMSF, $5 \mathrm{mM}$ iodoacetic acid) containing leupeptin and aprotinin $(1 \mu \mathrm{g} / \mathrm{ml})$. The extracts were centrifuged to remove insoluble material. Protein contents were determined using the BCA method. Equal amounts of proteins $(0.5 \mathrm{mg})$ for each experimental sample were incubated overnight at $4^{\circ} \mathrm{C}$ with the specific antibodies (mouse anti- $\alpha \mathrm{v} ß 3,2 \mu \mathrm{l}$; and rabbit anti-mouse, $10 \mu 1$ ). The antibody-integrin complexes were incubated for another $1 \mathrm{~h}$ with protein A-Sepharose (Pharmacia, Uppsala, Sweden), washed three times in RIPA buffer and three times in purified water. Proteins were separated by $6 \%$ SDS-PAGE, electrotransferred to nitrocellulose, incubated with peroxidase-conjugated streptavidin and visualized by chemiluminescence (SuperSignal Chemiluminescence Detection System; Pierce Biotechnology Inc.).

\section{Results}

IGF-I stimulates prostate cancer cell migration through the activation of IGF-IR. These studies were performed to clarify whether the IGF-I-induced activation of IGF-IR might affect the migratory properties of the androgen-independent prostate cancer cell lines, DU 145 and PC3. DU 145 cells, grown in complete medium (i.e. FBS-supplemented and, therefore, in the presence of growth factors), were treated for $1 \mathrm{~h}$ with a specific antibody against IGF-IR ( $\alpha$ IR3) before being seeded in the upper compartment of a Boyden's chamber (chemotactic assay). Fig. 1A shows that control DU 145 cells actively migrated towards the chemoattractant (20\% FBS); although, when the activity of IGF-IR was blocked by the specific antibody, the pro-migratory effect of serum was significantly reduced (Fig. 1A). Similar results were obtained using another androgen-independent prostate cancer cell line (PC3) (Fig. 1B). To confirm the specificity of the antibody, we showed that the presence of an aspecific antibody (human $\operatorname{IgG}$ ) did not affect the migration of either prostate cancer cell line (data not shown).

These results suggest that IGF-I might be involved in the control of the motile behavior of prostate cancer cells. To validate these observations, DU 145 cells, grown in the absence of serum, were treated with IGF-I ( $10 \mathrm{nM})$, either alone or in the presence of the function blocking antibody raised against IGF-IR. We observed that IGF-I significantly increased the migratory capacity of DU 145 cells; this effect was completely blocked by the simultaneous treatment of the cells with the IGF-IR antibody (Fig. 2A). When given alone, $\alpha$ IR3 did not affect the motility of the cells. Identical results were obtained with PC3 cells (Fig. 2B).

Collectively, these data demonstrate that IGF-I through the activation of its receptor, IGF-IR, exerts a pro-migratory activity on androgen-independent prostate cancer cells.

IGF-I induces lamellipodia formation and actin cytoskeleton rearrangements. The metastatic behavior of tumor cells is usually associated with change in cell morphology, actin polymerization and rearrangement of actin filaments. To correlate the data obtained from the migration assays with cell morphology, scanning electron microscopy was performed. Fig. 3B indicates the formation of lamellipodia in IGF-Itreated DU 145 cells with respect to controls (Fig. 3A). This 
macrograph also reveals that the bodies of IGF-I-treated cells did not adhere to the substratum.

The effects of IGF-I on cytoskeleton organization were analyzed by immunofluorescent staining using TRITC-

A

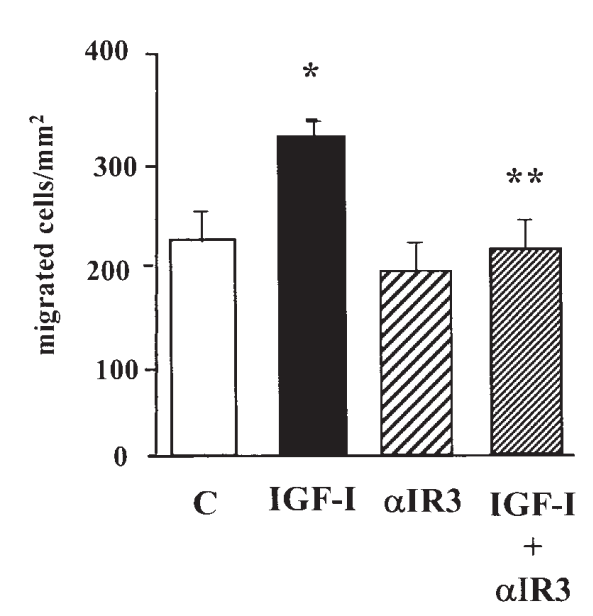

B

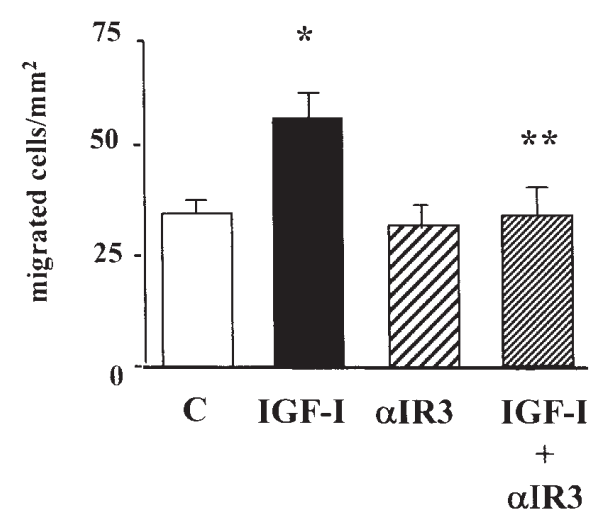

Figure 2. Effect of IGF-I, either in the absence or presence of the neutralizing antibody, anti-IGF-IR $\alpha$ IR3, on the motility of androgen-independent prostate cancer cells (DU 145 and PC3). Cells, grown in the absence of serum, were treated with IGF-I alone (10 nM, $24 \mathrm{~h})$, with $\alpha \mathrm{IR} 3$ alone $(1 \mu \mathrm{g} / \mathrm{ml}, 1 \mathrm{~h})$, or with IGF-I ( $24 \mathrm{~h}$ ) in the presence of $\alpha \mathrm{IR} 3$ (during the last hour of incubation). The chemomigration assay was then performed as outlined in Materials and methods. Results are expressed as the mean number of migrated cells/ $\mathrm{mm}^{2} \pm$ SE. C, controls. ${ }^{*} \mathrm{P}<0.05$ vs. C; ${ }^{* *} \mathrm{P}<0.05$ vs. IGF-I. phalloidin, which shows high affinity for the actin cytoskeleton. Fig. 4 shows that, in DU 145 cells, IGF-I induced an arrangement of the actin cytoskeleton in stress fibers and an increased intensity of actin immunofluorescence in peripheral areas below the cell membrane (Fig. 4).

The PI3-K/Akt signaling pathway mediates the pro-migratory activity of IGF-I. The activation of the PI3-K/Akt and MAP kinase signaling pathways by IGF-I has been reported to be deeply involved in the growth of several tumors, including prostate cancer $(8,15,24,25)$. In DU 145 cells, in particular, IGF-I has been previously demonstrated to stimulate Akt and ERK1/2 phosphorylation $(25,26)$. Experiments have been performed to clarify whether these pathways might mediate the pro-migratory activity of IGF-I in DU 145 androgenindependent prostate cancer cells. Therefore, we measured the effects of the PI3-K inhibitor, LY294002, and of the MAP kinase inhibitor, UO126, on IGF-I-induced DU 145 cell migration. Fig. 5A shows that, as expected, IGF-I stimulated the migratory activity of the cells while LY294002, when given alone, did not modify their motile behavior. Pretreatment of DU 145 cells with LY294002 completely counteracted the pro-migratory effect of the growth factor. On the contrary, Fig. 5B shows that UO126 was not able to affect the IGF-Iinduced migration of DU 145 cells. Thus, IGF-I-stimulated motility of prostate cancer cells seems to depend on the activation of the PI3-K/Akt signaling pathway.

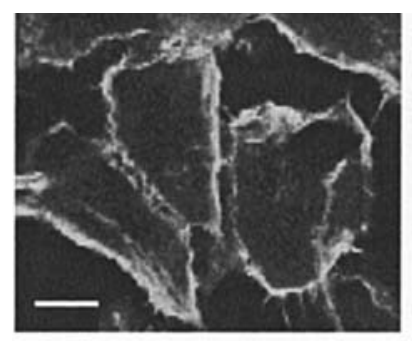

C

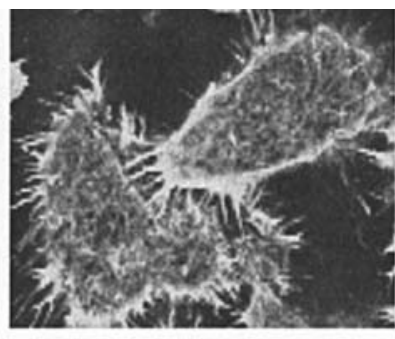

IGF-I
Figure 4. Immunofluorescence staining of F-actin showing the effects of IGF-I on the actin cytoskeleton organization of DU 145 cells. IGF-I (10 nM) induces a change in cell morphology with formation of lamellipodia and a redistribution of the actin cytoskeleton with an increased intensity of the immunofluorescence in peripheral areas below the cell membrane and along the leading edge of the lamellipodia. Scale bar, $16 \mu \mathrm{m}$.
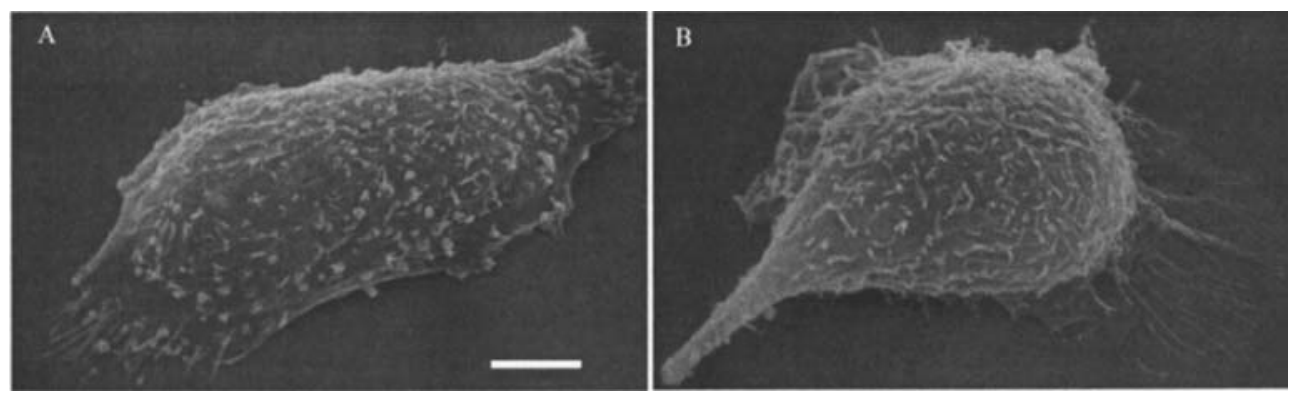

Figure 3. Scanning electron microscopy of serum-starved DU 145 cells, untreated (A) and treated with IGF-I (10 nM) (B). In DU 145 cells, IGF-I induced the formation and extension of lamellipodia. Scale bar, $10 \mu \mathrm{m}$. 
A

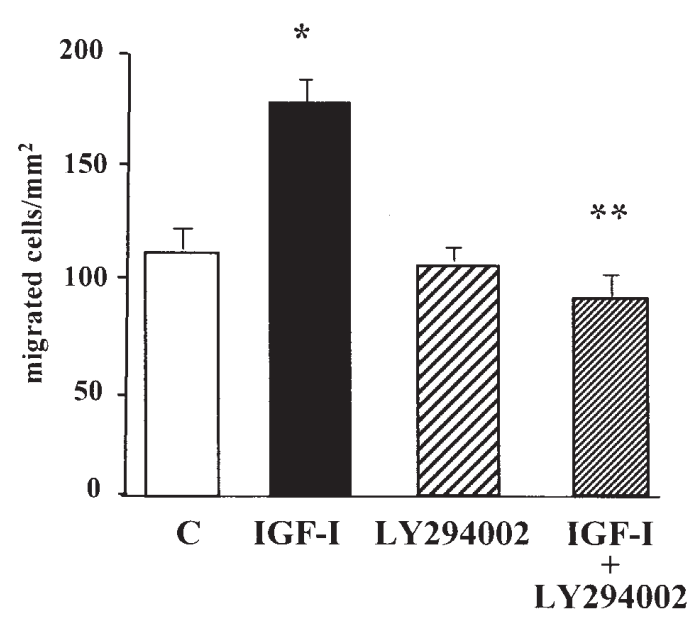

B

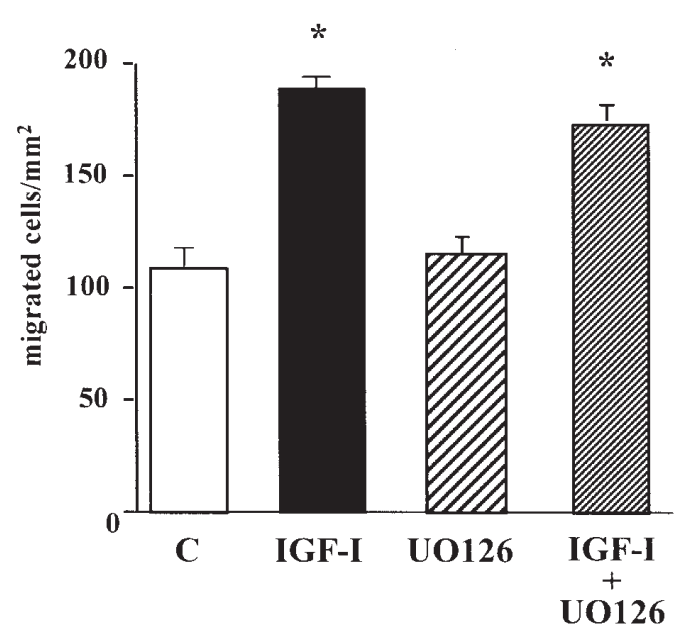

Figure 5. Involvement of the PI3-K/Akt and of the MAP kinase signaling pathways in the pro-motility activity of IGF-I on DU 145 cells. DU 145 cells, in serum-free medium, were incubated with LY294002 $(20 \mu \mathrm{M})(\mathrm{A})$ or with UO126 $(10 \mu \mathrm{M})(\mathrm{B})$ for $45 \mathrm{~min}$ before treatment with IGF-I (10 $\mathrm{nM})$ for 30 min. The chemomigration assay was then performed as outlined in Materials and methods. Results are expressed as the mean number of migrated cells $/ \mathrm{mm}^{2} \pm$ SE. C, controls. ${ }^{*} \mathrm{P}<0.05$ vs. $\mathrm{C} ;{ }^{* *} \mathrm{P}<0.05$ vs. IGF-I.

Anti- $\alpha v \beta 3$ integrin antibody blocks the IGF-I-induced migration of prostate cancer cells. The avß3 integrin dimer, highly expressed in androgen-independent prostate cancer cells, has been suggested to be involved in the processes of prostate cancer cell motility (27). These studies were performed to clarify whether the $\alpha \mathrm{v} ß 3$ integrin might play some role in IGF-I-induced DU 145 cell migration towards fibronectin. These experiments were performed by means of a haptotactic assay, which allows the determination of the migration of the cells towards a specific extracellular matrix ligand (fibronectin) for the integrin of interest ( $\alpha \mathrm{v} ß 3)$. In preliminary experiments, we showed that pre-treatment of the cells $(30 \mathrm{~min})$ cultured in complete medium with a monoclonal antibody (function blocking) against $\alpha \mathrm{v} \beta 3$ significantly reduced the ability of the cells to move towards fibronectin (Fig. 6A), confirming the crucial role of this integrin in the motility behavior of prostate cancer cells. The motility of the cells was not affected by the presence of an aspecific antibody (human $\mathrm{IgG}$ ) (data not shown). By using the same haptotactic assay, we further
A

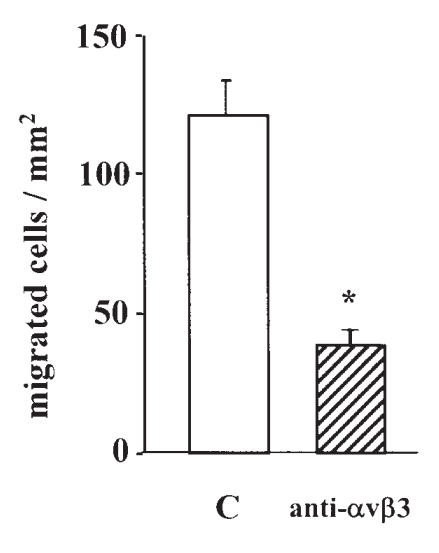

B

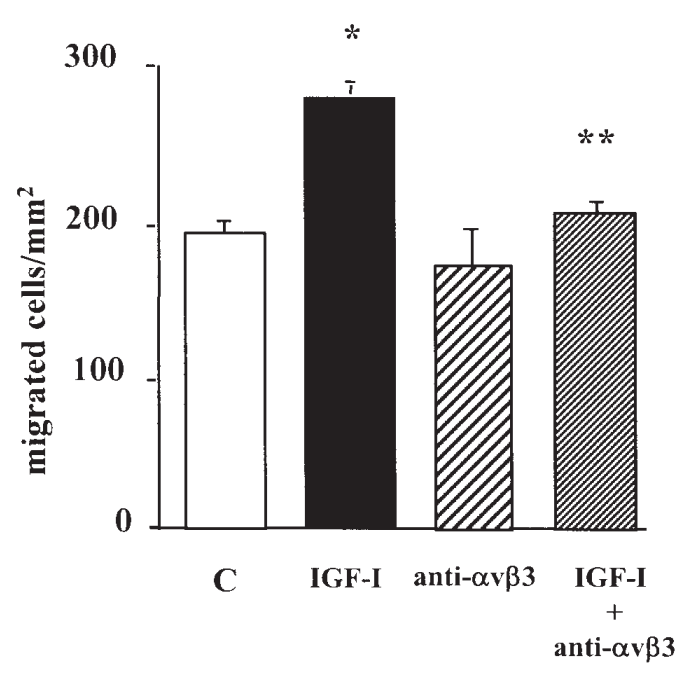

Figure 6 . Role of the $\alpha \mathrm{v} ß 3$ integrin in the pro-migratory activity of IGF-I on androgen-independent prostate cancer cells. These experiments have been performed by means of a haptotactic assay, as outlined in Materials and methods. (A) Effect of a function blocking antibody against $\alpha \mathrm{vB3}(1 \mu \mathrm{g} / \mathrm{ml}$, for $1 \mathrm{~h}$ ) on the motility of DU 145 cells, grown in complete medium, towards fibronectin. (B) Effect of IGF-I, either in the absence or in the presence of the antibody anti- $\alpha \mathrm{V} \beta 3$, on the motility of DU 145 cells towards fibronectin. Cells grown in the absence of serum were stimulated with IGF-I alone $(10 \mathrm{nM}, 24 \mathrm{~h})$, with anti- $\alpha \mathrm{vB3}(1 \mu \mathrm{g} / \mathrm{ml}, 1 \mathrm{~h})$, or with IGF-I $(24 \mathrm{~h})$ in the presence of anti- $\alpha$ VB3 (during the last hour of incubation). Results are expressed as the mean number of migrated cells $/ \mathrm{mm}^{2} \pm \mathrm{SE} .{ }^{*} \mathrm{P}<0.05$ vs. controls $(\mathrm{C}) ;{ }^{* *} \mathrm{P}<0.05$ vs. IGF-I.

demonstrated that the migration of DU 145 cells cultured in serum-free medium was significantly stimulated by IGF-I; the function blocking antibody against avß3 completely reversed the action of IGF-I (Fig. 6B). Anti- $\alpha$ vß3, when given alone, did not affect cell migration (Fig. 6B).

IGF-I increases avß3 integrin immunofluorescence through $P I 3-K / A k t$. The experiments described above indicate that the activity of $\alpha \mathrm{v} \beta 3$ is crucial for IGF-I to exert its pro-migratory effect. We then tested whether the growth factor might affect also the expression and/or the cellular distribution of the integrin in DU 145 cells. Using immunofluorescence, we showed, after $30 \mathrm{~min}$ of treatment with the growth factor, an increased intensity of the fluorescence corresponding to $\alpha \mathrm{v} ß 3$, 


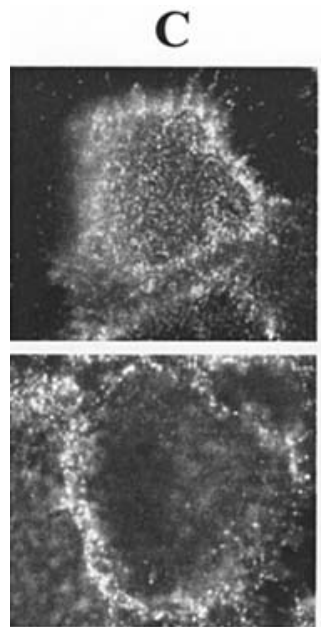

LY294002

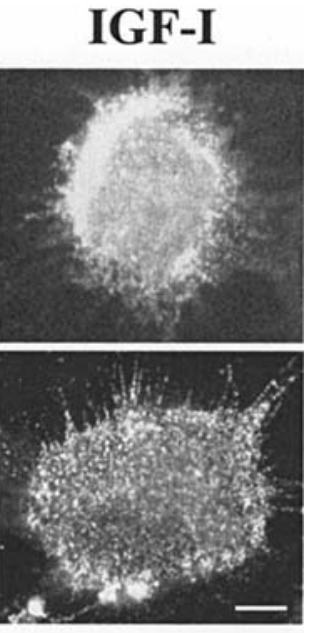

IGF-I +

\section{LY294002}

Figure 7. Effect of IGF-I on $\alpha \mathrm{v} ß 3$ immunofluorescence. DU 145 cells were treated with LY294002 (20 $\mu \mathrm{M}, 45 \mathrm{~min})$ before treatment with IGF-I (10 nM) for $30 \mathrm{~min}$. Immunofluorescence analysis reveals, in IGF-I-treated cells, an increased intensity of $\alpha \mathrm{v} B 3$ staining which is mainly localized at the level of the cell membranes; the blockade of PI3-K activity counteracts the increased intensity of $\alpha v \beta 3$ staining induced by IGF-I. C, controls. Scale bar, $16 \mu \mathrm{m}$.

which is mainly localized at the level of the cell membrane (Fig. 7). The PI3-K inhibitor, LY294002, clearly antagonized this effect (Fig. 7). These data demonstrate that the promigratory activity of IGF-I on androgen-independent prostate cancer cells is mediated by an increased expression of $\alpha \mathrm{v} ß 3$ fluorescence at the level of the cell membrane, and this effect is mediated by the PI3-K/Akt pathway.

IGF-I increases $\alpha v \beta 3$ protein expression. Experiments were performed to clarify whether IGF-I might affect also the expression of $\alpha \mathrm{v} ß 3$ at the protein level. A 24-h period of treatment with the growth factor was selected in order to detect possible modifications of protein synthesis. Cells were treated with the growth factor for $24 \mathrm{~h}$. By biothynilation, immunoprecipitation and Western blot analysis, we demonstrated that the treatment of the cells with IGF-I increased the expression of $\alpha v ß 3$ protein (Fig. 8); interestingly, this effect was not modified by a co-treatment of the cells with LY294002 (data not shown). These data indicate that the PI3-K/Akt pathway might not mediate the effects of IGF-I on the expression of the $\alpha \mathrm{v} \beta 3$ protein.

It is known that Akt phosphorylation represents a very rapid event in the action of IGF-I. Therefore, it is possible that the activation of this kinase might play a crucial role in triggering the early molecular events of the migratory response of the cells (such as $\alpha \mathrm{v} \beta 3$ cellular localization) to the growth factor; delayed effects, such as regulation of $\alpha v ß 3$ protein expression, might involve different mediators placed downstream in the IGF-I signaling cascade.

\section{Discussion}

The data reported in this paper represent the first demonstration that IGF-I, through the activation of its specific

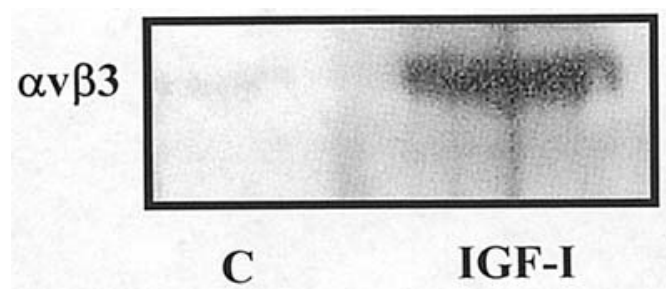

Figure 8 . Effect of IGF-I on $\alpha \mathrm{v} ß 3$ protein expression. DU 145 cells were treated with IGF-I $(10 \mathrm{nM})$ for $24 \mathrm{~h}$; protein levels were evaluated by Western blotting after protein biothynilation and immunoprecipitation. One of three experiments is reported.

receptor, IGF-IR, promotes the motility of androgenindependent prostate cancer cells (both DU 145 and PC3). The increased migratory ability of the cells is accompanied by the formation of lamellipodia, extending in multiple directions and by actin cytoskeletal reorganization. Since IGF-I-induced migration is completely antagonized by the presence of a specific PI3-K inhibitor (but not by the presence of a MAP kinase inhibitor), we conclude that the pro-migratory effect of the growth factor specifically requires the activation of the PI3-K/Akt signaling pathway.

In agreement with our observations, Grzmil and coworkers (28) recently reported that the blockade of IGF-IR expression in androgen-independent prostate cancer PC3 cells results in a significant suppression of the invasive behavior of the cells (ability of the cells to invade a Matrigel preparation), which is accompanied by up-regulation of IGF binding protein-3 and suppression of matrix metalloproteinase-2 (MMP-2) expression.

The crucial role of IGF-I, both serum-derived and locally produced, in the control of prostate cancer cell proliferation has been widely demonstrated in our laboratory (13) and others $(10-12,14)$. The data here demonstrate that IGF-I promotes not only the growth but also the metastatic (migratory and invasive) behavior of prostate cancer cells.

The pro-migratory activity of IGF-I in prostate cancer is in line with previous observations obtained in other types of tumors $(24,29)$. IGF-I has been shown to increase cell motility in breast cancer cells $(30,31)$; this effect is accompanied by the formation of motile actin microspikes at the level of cell-cell contact and disorganization of adherens junctions (30). Moreover, in highly metastatic breast cancer cells, the transfection of the dominant negative forms of IGF-IR abrogated cellular motility and adhesion to extracellular matrix proteins (laminin and collagen), and inhibited IGF-Istimulated invasion through collagen $(32,33)$. When injected into the mammary fat pad, breast cancer cells expressing the dominant negative IGF-IR did not give rise to metastases, especially to the lungs (33). IGF-I has been found to stimulate both the migratory and invasive behavior of colon cancer cells, either in vitro or in vivo (when grown in nude mice); this effect is accompanied by increased activity of the urokinase plasminogen activator (uPA)/uPAR system, a key mediator of tumor cell metastatic behavior (34-36). In lung carcinoma cell lines, IGF-I has been demonstrated to increase the invasive and motile capabilities of the cells and this action was accompanied by an up-regulation of the activity of matrix metalloproteinases (MMPs), such as MMP-2 and MMP-9 
(37-39). Finally, Tai and coworkers (40) have shown that IGF-I induces both adhesion and migration in myeloma cells, through the activation of the $\beta 1$ integrin.

In this study, we investigated whether cell adhesion molecules, such as integrins, might be involved in the promigratory activity of IGF-I on prostate cancer cells. We have first shown that $\alpha \mathrm{v} B 3$ integrin is deeply involved in the control of the motility of DU 145 cells, since a function blocking antibody against this integrin dimer completely suppressed the migration of the cells towards fibronectin, one of its extracellular matrix ligands. The level of expression of the avß3 integrin has been previously shown to positively correlate with the grade of malignancy of prostate cancer. This integrin is not expressed in androgen-dependent, poorly aggressive, LNCaP cells, while it is expressed at high levels in androgenindependent, strongly metastatic, PC3 cells (22). Exogenous expression of $\alpha \mathrm{vB3}$ in LNCaP cells results in increased cell adhesion to and migration on vitronectin (22), in an activation of the PI3-K/Akt pathway (41) and in increased levels of cdc2 protein and kinase activity (27). We then demonstrated that a function blocking antibody against $\alpha \mathrm{v} ß 3$ completely abrogated the IGF-I-induced migration of DU 145 cells in a haptotactic assay. IGF-I also increased avß3 immunofluorescence, which localized mainly at the membrane level, and this effect was counteracted by the blockade of the PI3-K activity. Collectively, these data indicate that IGF-I promotes the motile behavior of androgen-independent prostate cancer cells through $\alpha \mathrm{v} B 3$ integrin activation/expression and that this effect appears to be mediated by the PI3-K/Akt signaling pathway.

Our observations are in line with recent studies on nonmalignant cells; the $\alpha \mathrm{v} ß 3$ integrin dimer has been shown to be required for IGF-I to stimulate the proliferation and migration of smooth muscle cells (42), extravillous trophoblast cells (43), and preadipocyte 3T3-L1 cells (44). In smooth muscle cells, the intracellular proteins (DOK1, SHP-2) that are recruited to the $B 3$ subunit of the dimer following IGF-IR stimulation, have also been identified (45-47).

The data so far available on the possible role of $\alpha v \beta 3$ in the IGF-I-induced modulation of proliferation and motility in cancer cells are still scanty and, apparently, have led to divergent conclusions. Pereira and coworkers have recently reported that, in MCF-7 breast cancer cells, stable epression of $\alpha \mathrm{v} ß 3$ abrogates the IGF-I-mediated migration of the cells through its interaction with IGF-binding protein-2 (IGFBP-2) (48). These data, supporting a negative regulatory role of $\alpha \mathrm{v} B 3$ in the chemotactic activity of IGF-I in breast cancer cells, are in contrast with those reported in this paper. The reason for this discrepancy is unclear; however, it might be related to the different cancer cell types analyzed. In this context it must be underlined that, according to Pereira and coworkers (48), avß3 expression seems to be down-regulated in breast tumors when compared to that in non-neoplastic breast tissue. As already reported, in prostate cancer, the expression of the integrin positively correlates with the level of malignancy of the tumor. Moreover, MCF-7 cells lack expression of $\alpha \mathrm{v} ß 3$, which is, in contrast, highly expressed in the prostate cancer cells utilized in the present study.

In conclusion, the data reported in this paper demonstrate that: i) IGF-I promotes the motile behavior of androgen- independent prostate cancer cells, through avß3 integrin activation/expression; ii) these effects are mediated by the PI3-K/Akt signaling pathway. These results support a role for IGF-I in the progression of prostate cancer towards the metastatic phase (in addition to its role in the growth of the tumor), and provide an additional rationale basis for the development of therapeutic strategies involving the IGF-I/ IGF-IR system in the treatment of prostate cancer.

\section{Acknowledgements}

This study was supported by CEO (Center for Endocrinological Oncology) and by MIUR-COFIN.

\section{References}

1. Jemal A, Murray T, Ward E, Samuels A, Tiwari RC, Ghafoor A, Feuer EJ and Thun MJ: Cancer statistics, 2005. CA Cancer J Clin 55: 10-30, 2005.

2. Miyamoto $\mathrm{H}$, Messing EM and Chang $\mathrm{C}$ : Androgen deprivation therapy for prostate cancer: current status and future prospects. Prostate 61: 332-353, 2004

3. Lee ECY and Tenniswood MPR: Emergence of metastatic hormone-refractory disease in prostate cancer after anti-androgen therapy. J Cell Biochem 91: 662-670, 2004.

4. Arnold JT and Isaacs JT: Mechanisms involved in the progression of androgen-independent prostate cancers: it is only the cancer cell's fault. Endocr-Rel Cancer 9: 61-73, 2002.

5. Navarro D, Luzardo OP, Fernandez L, Chesa N and DiazChico BN: Transition to androgen-independence in prostate cancer. J Steroid Biochem Mol Biol 81: 191-201, 2002.

6. Martel CL, Gumerlock PH, Meyers FJ and Lara PN: Current strategies in the management of hormone refractory prostate cancer. Cancer Treat Rev 29: 171-187, 2003.

7. Assikis VJ and Simons JW: Novel therapeutic strategies for androgen-independent prostate cancer: an update. Semin Oncol 31: 26-32, 2004

8. Pollak MN, Schernhammer ES and Hankinson SE: Insulin-like growth factors and neoplasia. Nat Rev Cancer 4: 505-518, 2004.

9. Djavan B, Waldert M, Seitz C and Marberger M: Insulin-like growth factors and prostate cancer. World J Urol 19: 223-225, 2001.

10. Iwamura M, Sluss PM, Casamento JB and Cockett ATK: Insulin-like growth factor I: action and receptor characterization in human prostate cancer cell lines. Prostate 22: 243-252, 1993.

11. Connolly JM and Rose DP: Regulation of DU145 human prostate cancer cell proliferation by insulin-like growth factors and its interaction with the epidermal growth factor autocrine loop. Prostate 24: 167-175, 1994.

12. Kimura G, Kasuya J, Giannini S, Honda Y, Mohan S, Kawachi M, Akimoto $\mathrm{M}$ and Fujita-Yamaguchi $\mathrm{Y}$ : Insulin-like growth factor (IGF) system components in human prostatic cancer cell lines: LNCaP, DU145 and PC-3 cells. Int J Urol 3: 39-46, 1996.

13. Montagnani Marelli M, Moretti RM, Dondi D, Motta M and Limonta P: Luteinizing hormone-releasing hormone agonists interfere with the mitogenic activity of the insulin-like growth factor system in androgen-independent prostate cancer cells. Endocrinology 140: 329-334, 1999.

14. Burfeind P, Chernicky CL, Rininsland F and Ilan J: Antisense RNA to the type I insulin-like growth factor receptor suppresses tumor growth and prevents invasion by rat prostate cancer cells in vivo. Proc Natl Acad Sci USA 93: 7263-7268, 1996.

15. Krueckl SL, Sikes RA, Edlund NM, Bell RH, Hurtado-Coll A, Fazli L, Gleave ME and Cox ME: Increased insulin-like growth factor I receptor expression and signaling are components of androgen-independent progression in a lineage-derived prostate cancer progression model. Cancer Res 64: 8620-8629, 2004.

16. Nickerson T, Chang F, Lorimer D, Smeekens SP, Sawyers CL and Pollak M: In vivo progression of LAPC-9 and LNCaP prostate cancer models to androgen independence is associated with increased expression of insulin-like growth factor I (IGF-I) and IGF-I receptor (IGF-IR). Cancer Res 61: 6276-6280, 2001.

17. Kaplan PJ, Mohan S, Cohen P, Foster BA and Greenberg NM: The insulin-like growth factor axis and prostate cancer: lessons from the transgenic adenocarcinoma of mouse prostate (TRAMP) model. Cancer Res 59: 2203-2209, 1999. 
18. Chan JM, Stampfer MK, Giovannucci E, Gann PH, Ma J, Wilkinson P, Hennekens CH and Pollak M: Plasma insulin-like growth factor-I and prostate cancer risk: a prospective study. Science 279: 563-566, 1998.

19. Stattin P, Bylund A, Rinaldi S, Biessy C, Dechaud H, Stenman UH, Egevad L, Riboli E, Hallmans G and Kaaks R: Plasma insulin-like growth factor-I, insulin-like growth factorbinding proteins and prostate cancer risk: a prospective study. $\mathbf{J}$ Natl Cancer Inst 92: 1910-1917, 2000.

20. Hellawell GO, Turner GDH, Davies DR, Poulsom R, Brewster SF and Macaulay VM: Expression of the type 1 insulin-like growth factor receptor is up-regulated in primary prostate cancer and commonly persists in metastatic disease. Cancer Res 62: 2942-2950, 2002

21. Hood JD and Cheresh DA: Role of integrins in cell invasion and migration. Nat Rev Cancer 21: 91-100, 2002.

22. Zheng D-Q, Woorward AS, Fornaro M, Tallini G and Languino LR: Prostatic carcinoma cell migration via $\alpha \mathrm{V} ß 3$ integrin is modulated by a focal adhesion kinase pathway. Cancer Res 59: 1655-1664, 1999.

23. Moretti RM, Montagnani Marelli M, Motta M and Limonta P: Role of the orphan nuclear receptor ROR $\alpha$ in the control of the metastatic behavior of androgen-independent prostate cancer cells. Oncol Rep 9: 1139-1143, 2002.

24. Grimberg A: Mechanisms by which IGF-I may promote cancer. Cancer Biol Ther 2: 630-635, 2003.

25. Klein RD and Fischer SM: Black tea polyphenols inhibit IGF-Iinduced signaling through Akt in normal prostate epithelial cells and DU145 prostate carcinoma cells. Carcinogenesis 23: 217-221, 2002.

26. Putz T, Culig Z, Eder IE, Nessler-Menardi C, Bartsch G, Grunicke $\mathrm{H}$, Uberall $\mathrm{F}$ and Klocker $\mathrm{H}$ : Epidermal growth factor (EGF) receptor blockade inhibits the action of EGF, insulin-like growth factor I and protein kinase A activator on the mitogenactivated protein kinase pathway in prostate cancer cell lines. Cancer Res 59: 227-233, 1999.

27. Manes T, Zheng DQ, Tognin S, Woodard AS, Marchisio PC and Languino LR: Alpha(v)beta3 integrin expression up-regulates cdc2, which modulates cell migration. J Cell Biol 161: 817-826, 2003.

28. Grzmil M, Hemmerlein B, Thelen P, Schweyer S and Burfeind P: Blockade of the type I IGF receptor expression in human prostate cancer cells inhibits proliferation and invasion, up-regulates IGF binding protein-3 and suppresses MMP-2 expression. J Pathol 202: 50-59, 2004.

29. Zhang H and Yee D: The therapeutic potential of agents targeting the type I insulin-like growth factor receptor. Exp Opin Invest Drugs 13: 1569-1577, 2004.

30. Jackson JG, Zhang X, Yoneda Y and Yee D: Regulation of breast cancer cell motility by insulin receptor substrate-2 (IRS-2) in metastatic variants of human breast cancer cell lines. Oncogene 20: 7318-7325, 2001

31. Guvakova MA, Adams JC and Boettiger D: Functional role of alpha-actinin, PI 3-kinase and MEK1/2 in insulin-like growth factor I receptor kinase regulated motility of human breast carcinoma cells. J Cell Sci 115: 4149-4165, 2002.

32. Dunn SE, Ehrlich M, Sharp NJ, Reiss K, Solomon G, Hawkins R, Baserga R and Barrett JC: A dominant negative mutant of the insulin-like growth factor-I receptor inhibits the adhesion, invasion and metastasis of breast cancer. Cancer Res 58: 3353-3361, 1998.

33. Sachdev D, Hartell JS, Lee AV, Zhang X and Yee D: A dominant negative type I insulin-like growth factor receptor inhibits metastasis of human cancer cells. J Biol Chem 279: 5017-5024, 2004.

34. Reinmuth N, Fan F, Liu W, Parikh AA, Stoeltzing O, Jung YD, Bucana CD, Radinsky R, Gallick GE and Ellis LM: Impact of insulin-like growth factor receptor-I function on angiogenesis, growth and metastasis of colon cancer. Lab Invest 82: 1377-1389, 2002 .
35. Wu Y, Yakar S, Zhao L, Hennighausen L and LeRoith D: Circulating insulin-like growth factor-I levels regulate colon cancer growth and metastasis. Cancer Res 62: 1030-1035, 2002.

36. Bauer TW, Fan F, Liu W, Johnson M, Parikh NU, Parry GC, Callahan J, Mazar AP, Gallick GE and Ellis LM: Insulin-like growth factor-I-mediated migration and invasion of human colon carcinoma cells requires activation of c-Met and urokinase plasminogen activator receptor. Ann Surg 241: 748-758, 2005.

37. Bredin CG, Liu Z and Klominek J: Growth factor-enhanced expression and activity of matrix metalloproteases in human nonsmall cell lung cancer cell lines. Anticancer Res 23: 4877-4884, 2003.

38. Samani AA, Chevet E, Fallavollita L, Galipeau J and Brodt P: Loss of tumorigenicity and metastatic potential in carcinoma cells expressing the extracellular domain of the type 1 insulinlike growth factor receptor. Cancer Res 64: 3380-3385, 2004.

39. Zhang D, Bar-Eli M, Meloche S and Brodt P: Dual regulation of MMP-2 expression by the type 1 insulin-like growth factor receptor: the phosphatidylinositol 3-kinase/Akt and Raf/ERK pathways transmit opposing signals. J Biol Chem 279: 19683-19690, 2004.

40. Tai Y-T, Podar K, Catley L, Tseng Y-H, Akiyama M, Shringarpure R, Burger R, Hideshima T, Chauhan D, Mitsiades N, Richardson P, Munshi NC, Kahn CR, Mitsiades C and Anderson KC: Insulin-like growth factor-1 induces adhesion and migration in human multiple myeloma cells via activation of $\beta 1$-integrin and phosphatidylinositol 3'-kinase/AKT signaling. Cancer Res 63: 5850-5858, 2003.

41. Zheng DQ, Woodard AS, Tallini G and Languino LR: Substrate specificity of $\alpha \mathrm{v} \beta 3$ integrin-mediated cell migration and phosphatidylinositol 3-kinase/AKT. J Biol Chem 275: 24565-24574, 2000 .

42. Clemmons DR, Horvitz G, Engleman W, Nichols T, Moralez A and Nickols GA: Synthetic alphaVbeta3 antagonists inhibit insulin-like growth factor-I-stimulated smooth muscle cell migration and replication. Endocrinology 140: 4616-4621, 1999.

43. Kabir-Salmani M, Shiokawa S, Akimoto Y, Sakai K, Nagamatsu S, Sakai K, Nakamura Y, Lotfi A, Kawakami H and Iwashita M: $\alpha v B 3$ integrin signalling pathway is involved in insulin-like growth factor I-stimulated human extravillous trophoblast cell migration. Endocrinology 144: 1620-1630, 2003.

44. Sekimoto H, Eipper-Mains J, Pond-Tor S and Boney CM: $\alpha v B 3$ integrins and Pyk2 mediate IGF-I activation of Src and MAPK in 3T3-L1 cells. Mol Endocrinol 19: 1859-1867, 2005.

45. Maile LA and Clemmons DR: The alphaVbeta 3 integrin regulates insulin-like growth factor I (IGF-I) receptor phosphorylation by altering the rate of recruitment of the Src-homology 2-containing phosphotyrosine phosphatase-2 to the activated IGF-I receptor. Endocrinology 143: 4259-4264, 2002.

46. Ling Y, Maile LA and Clemmons DR: Tyrosine phosphorylation of the beta3-subunit of the alphaVbeta3 integrin is required for membrane association of the tyrosine phosphatase SHP-2 and its further recruitment to the insulin-like growth factor I receptor. Mol Endocrinol 17: 1824-1833, 2003.

47. Ling Y, Maile LA, Badley-Clarke J and Clemmons DR: DOK1 mediates SHP-2 binding to the alphaVbeta3 integrin and thereby regulates insulin-like growth factor I signalling in cultured vascular smooth muscle cells. J Biol Chem 280: 3151-3158, 2005.

48. Pereira JJ, Meyer T, Docherty SE, Reid HH, Marshall J, Thompson EW, Rossjohn J and Price JT: Bimolecular interaction of insulin-like growth factor (IGF) binding protein-2 with avß3 negatively modulates IGF-I-mediated migration and tumor growth. Cancer Res 64: 977-984, 2004. 